\title{
The effect of sesame intake on adult albino rat testis during sildenafil long-term administration
}

\author{
M. Goweder Fawzia', T. M. Abu El-Nasr ${ }^{2}$ and A. A. El-Sayed ${ }^{2,3^{*}}$
}

\begin{abstract}
Background: Sildenafil (Viagra) is widely used for the treatment of erectile dysfunction under various etiologies. Unfortunately, chronic administration of sildenafil negatively affects fertility. The aim of the present study is to investigate the improvement role of sesame on the testis alterations caused by long-term administration of sildenafil on albino rats.

Results: Light microscopically observations showed that overdoses of sildenafil had provoked tubular and interstitial histological alterations. Tubular degeneration and abnormality in the germinal epithelium of the seminiferous tubules included spermatocyte degeneration and arrest of spermatogenesis. Sperm count and motility were negatively affected by sildenafil. These alterations were improved by sesame feeding.

Conclusion: Sesame intake improve the side effects of prolonged treatment with sildenafil significantly. These results demonstrate the pivotal role of sesame that may improve male infertility.
\end{abstract}

Keywords: Sesame, Sildenafil, Testis, Sperm count, Motility

\section{Background}

Sildenafil citrate (Viagra), a water-soluble citrate salt, was firstly used to treat hypertension and angina pectoris and pulmonary arterial hypertension. Sildenafil citrate acts by inhibiting cyclic guanosine monophosphate (Salam, Rokonujjaman, Rahman, Sultana, \& Sultan, 2015). Viagra exhibited a different pharmacological effect, a marked penile erection, and became the first-line treatment option of erectile dysfunction (Conti et al. 1999; Kalsi \& Kell, 2004; Uthayathas et al., 2007). The drug has been found to be effective and well tolerated in men with mild to moderate erectile dysfunction of no clinically identifiable organic cause (Eardley, 2001). Sildenafil citrate is known for its vasodilatory effects on

\footnotetext{
*Correspondence: abosharaf63@yahoo.com

${ }^{2}$ Zoology Department, Faculty of Science, Zagazig University, Zagazig 44519, Egypt

${ }^{3}$ Zoology Department, Faculty of Science, Islamic University of Madinah, Medina, Saudi Arabia

Full list of author information is available at the end of the article
}

cardiac muscle of humans (Corbin et al., 2003), and its protective effect in animal's hearts like rabbit, rat, and mouse (Salloum, Yin, Xi, \& Kukreja, 2003). In addition, to the cardiovascular system, reported research showed that sildenafil also cuts across the respiratory system (Goldberg, French, McBride, Marino, \& Mirarchi, 2011), nervous system (Fazan Jr. et al., 2008; Kyratsas et al., 2013), gastrointestinal tract (Eherer et al., 2002), and renal system (Eherer et al., 2002; Lauver, Carey, Bergin, Lucchesi, \& Gurm, 2014), as well as the liver (Eweka \& Eweka, 2011; Ji et al., 2005). Although no clinically adverse homodynamic effects were observed when sildenafil was used by healthy men (Cheitlin, Hutter, Brindis, Ganz, \& Kaul, 1999), many side effects had been reported such as flushing, headache, congestion, and dyspepsia.

Sesame (Sesame radiatum) belongs to the family Pedaliaceae (Zavareh, Hoogenboom, Rahimian, \& Arabd, 2008). The sesame seeds are high-energy-yielding food and contain many health-promoting nutrients, minerals,

\section{Springer Open}

(c) The Author(s). 2021 Open Access This article is licensed under a Creative Commons Attribution 4.0 International License, which permits use, sharing, adaptation, distribution and reproduction in any medium or format, as long as you give appropriate credit to the original author(s) and the source, provide a link to the Creative Commons licence, and indicate if changes were made. The images or other third party material in this article are included in the article's Creative Commons licence, unless indicated otherwise in a credit line to the material. If material is not included in the article's Creative Commons licence and your intended use is not permitted by statutory regulation or exceeds the permitted use, you will need to obtain permission directly from the copyright holder. To view a copy of this licence, visit http://creativecommons.org/licenses/by/4.0/. 
antioxidants, and vitamins; these are essential for human health (Borchani, Besbes, Blecker, \& Attia, 2010). Most of the sesame seeds are used for oil extraction, and the rest of the plant are used for edible purposes (El Khier, Ishag, \& Yagoub, 2008). Oil extracted from sesame is honored as a rich food because of its high nutritive quality and stability (Nayar \& Mehra, 2002). It has many uses, and it is markedly different from other vegetable oils due to its high nutritional and therapeutic values. Potential health benefits of sesame include anti oxidative, anticancer, anti-hypersensitive, and anti-immunoregulatory actions (Reshma, Balachandran, Arumughan, Sunderasan, \& Sukumaran, 2010). From the chemical composition of sesame, it is known that the seeds contain $50-60 \%$ oil, $18-25 \%$, protein, $13.5 \%$ carbohydrate, and $5 \%$ ash (Elleuch, Besbes, Roiseux, Blecker, \& Attia, 2007). They are good sources of vitamin B like niacin, thiamine, folic acid, pyridoxine, and riboflavin. It contains important minerals like potassium, phosphorus, magnesium, calcium, iron, manganese, zinc, selenium, copper, and sodium (Tunde-Akintunde, Oke, \& Akintunde, 2012). Sesame seeds contain large amounts of antioxidants and phytoestrogens, and it has been shown that this plant may have some beneficial effects on the reproductive parameters of male rats (Abbasi, Fatemi, Barati, Mazaheri, \& Morovati, 2013). However, due to the paucity of knowledge, the present study is designed to evaluate the effect of a diet which contains sesame on some sperm parameters and testicular alterations of male rats after long-term administration of Viagra.

\section{Methods}

\section{Drug and animals}

A. Drug: Sildenafil (Pfizer, USA) —-with trade name Viagra.

B. Animals: Forty-two rats were purchased (from an animal farm at Abu Rawash, Giza), each weighing about 190-200 g. Rats were allowed to free access to water and diet. All groups were maintained with 12-h: 12-h photo-period cycle at room temperature $\left(25 \pm 20^{\circ} \mathrm{C}\right)$. The experimental protocol was approved by the Ethics Committee and Animals Research.

\section{Experimental groups}

After a week of acclimation, the rats were randomly divided into six groups (7 rats/group) as the following:

- Group I (normal control group).

- Group II (positive control) was fed on sesame (sesame seeds is mixed with food by a ratio 1:1).

- Group III was administered sildenafil with dose 0.3 $\mathrm{mg} / \mathrm{kg}$ wt./day.
- Group IV was administered sildenafil with dose 0.6 $\mathrm{mg} / \mathrm{kg}$ wt./day.

- Group V was administered sildenafil with dose 0.3 $\mathrm{mg} / \mathrm{kg} \mathrm{wt}$./day and the food is mixed with sesame seeds by a ratio (1:1).

- Group VI was administered sildenafil with dose 0.6 $\mathrm{mg} / \mathrm{kg}$ wt./day and the food is mixed with sesame seeds by a ratio $(1: 1)$.

All the treated groups were extended for 12 successive weeks.

\section{Semen collection and sperm count}

At the end of the experiment, the team used anesthesia and then slaughtered them, collected blood, and extracted some organs in the experimental measurements. The epididymis of rats in each group were removed and squeezed gently in a sterile clean watch glass containing $1 \mathrm{ml}$ normal saline for some few minutes to allow the sperms to become motile and examined for sperm count according to the technique adopted by Saalu, Togun, Oyewopo, and Raji (2006) using pipette of hemocytometer. The semen was withdrawn up to the mark 0.1 and the pipette then filled up to the mark 1 by normal saline. Contents of the pipette were mixed by shaking. The cover slide was placed over the counting chamber, and a drop of diluted semen was spread between the hemocytometer slide and its cover. The sperms in 5 large squares were counted. The sperm cell concentrations in cubic milliliter were estimated.

\section{Sperm motility}

One hundred sperms were observed in three different fields, counted and classified into motile and non-motile. Motility was statistically estimated and expressed as percentage incidence.

\section{Statistical analysis}

The differences between all examined groups were compared by Student's $t$ test. Statistical analysis of data represented the mean $\pm \mathrm{SE}$. For statistical analysis, one-way analysis of variance (ANOVA) was applied and the statistical significance was set at $p<0.05$.

\section{Histological techniques}

Directly after sacrificing the examined animals, the testes were fixed in $10 \%$ neutral formalin fluid, routinely processed, dehydrated, embedded in paraffin wax and sectioned at $5 \mu \mathrm{m}$ thickness. Paraffin sections were stained with hematoxylin and eosin stain followed by techniques of (Drury \& Wallington, 1980). These sections were examined and photographed by light microscope. 
Table 1 Effect of sesame intake on sperm count of prolonged sildenafil-administered adult male rats

\begin{tabular}{llllll}
\hline Normal control & Positive control & Sildenafil $\mathbf{0 . 3} \mathbf{~} \mathbf{~ g} / \mathbf{k g}$ & Sildenafil $\mathbf{0 . 6} \mathbf{~} \mathbf{g} / \mathbf{k g}$ & Sild. + sesame $\mathbf{0 . 3} \mathbf{~} \mathbf{g} / \mathbf{k g}$ & Sild. + sesame $\mathbf{0 . 6} \mathbf{~} \mathbf{g} \mathbf{k g}$ \\
\hline 60.4 & 60.5 & 55.4 & 53.3 & 55.3 & 57.1 \\
60.3 & 64.3 & 52.5 & 52.2 & 56.7 & 56.9 \\
59.1 & 65.9 & 53.7 & 53.2 & 57.8 & 57.8 \\
58.6 & 59.8 & 55.1 & 55.1 & 54.4 & 55.7 \\
61.4 & 63.7 & 53.3 & 53.1 & 57.2 & 54.5 \\
62.2 & 59.7 & 50.9 & 50.1 & 55.4 & 43.7 \\
61.5 & 62.6 & 50.7 & 50.7 & 50.9 & 49.2 \\
\hline
\end{tabular}

Means with the same row are significant at $p<0.05$

\section{Results}

\section{Effect of sildenafil citrate on sperm count and motility}

Long-term administration of sildenafil $(0.3$ and $0.6 \mathrm{mg})$ in male rats caused a significant reduction in the number of sperms comparing with control group (Table 1). It was observed that the treatment with $0.6 \mathrm{mg}$ of sildenafil in male rats was more effective than in those treated with $0.3 \mathrm{mg}$ of sildenafil. Nevertheless, the mean epididymal sperm motility of the examined animals (groups III and IV) was significantly lower than control (group I). However, supplementation of the normal rat's diet with sesame significantly improve the total sperm count as well as motility as in group II (Table 2). Even though, there was a somewhat increase in the sperm count and motility in groups V and VI.

\section{Histological observations}

Microscopic examination testis sections of the control group of revealed rounded seminiferous tubules with regular outlines and flagella of mature sperms were seen filling the lumens of the seminiferous tubules (Fig. 1a). The interstitial spaces in and between the tubules contained interstitial cells of Leydig. Seminiferous tubules were lined by layers of germinal epithelium at different stages of spermatogenesis; this lining is consisted of Sertoli cells and germinal cells (Fig. 1b).

Microscopic examination of testis sections of Viagraadministered rats (groups III and IV) revealed germinal epithelium at different stages of spermatogenesis with decreased thickness of germ cell layers and detached

Table 2 Sperm analysis or andrological parameters of albino rats in all groups under study

\begin{tabular}{lll}
\hline Groups & Sperm count & Motility percentage \\
\hline Group I & $6.49 \times 10^{6}$ & $74.0 \pm 12.32$ \\
Group II & $4.65 \times 10^{6}$ & $60.0 \pm 5.64$ \\
Group III & $3.34 \times 10^{6}$ & $30.0 \pm 6.12$ \\
Group IV & $5.46 \times 10^{6}$ & $45.0 \pm 5.00$ \\
Group V & $4.44 \times 10^{6}$ & $33.2 \pm 3.44$ \\
Group VI & $5.54 \times 10^{6}$ & $31.1 \pm 2.36$ \\
\hline
\end{tabular}

germ cells, also increased number of Leydig cells and increased width of the interstitial spaces in-between the tubules (Fig. 2a). In addition, there is spermatogenic arrest and disruption of the epithelial lining of the tubules as well as impairment of spermatogenesis accompanied with degeneration of spermatogenic elements with reduction of sperms in the lumen and marked loss of maturing germ cells (Fig. 2b).

The effect of testicular lesions induced by prolonged administration of sildenafil is reduced in sesame-fed treatment rats (groups V and VI) compared with those of untreated groups. Administration of sesame together with Viagra causes a certain improvement of histological findings such as increased growing of spermatogenic cell layers, spermatogonia attained its architecture, and many spermatozoa appeared in seminiferous lumen. Moreover, thickening of the interstitial tissues and flourished Leydig cells were noticed in the interstitial spaces (Fig. 3a, b).

\section{Discussion}

Impairment of spermatogenesis is caused by sildenafil, which had provoked tubular and interstitial histological alterations of the seminiferous tubules, increased Leydig cell cellularity, and tubular degeneration (Jarrar, 2011). Sildenafil side effects are reversed by the activation of the steroidogenic pathway and testosterone secretion (Scipioni, Stefanini, Santone, \& Giorgi, 2005).

In the present study, there were histological changes in untreated groups as reducing in spermatogenic layers, detaching germ cells and arresting spermatogenesis at the level of primary spermatocytes, in addition to necrosis of the seminiferous tubules that may lead to impaired spermatogenesis. Furthermore, flourished and increased number of Leydig cells was realized. Germinal cell viability and their ability for mitotic divisions in seminiferous tubules are related to testosterone secretion by Leydig cells. Disorder in testosterone secretion by Leydig cells has harmful effects on male fertility (Yang et al., 2017).

In this respect, Gumus, Vatansever, Müezzinoglu, Müftüoglu, and Kaymaz (2004) found abnormalities in the testis of rat due to increased dose of sildenafil. Tuorkey and Abdul Aziz (2012) found that increased dose of 


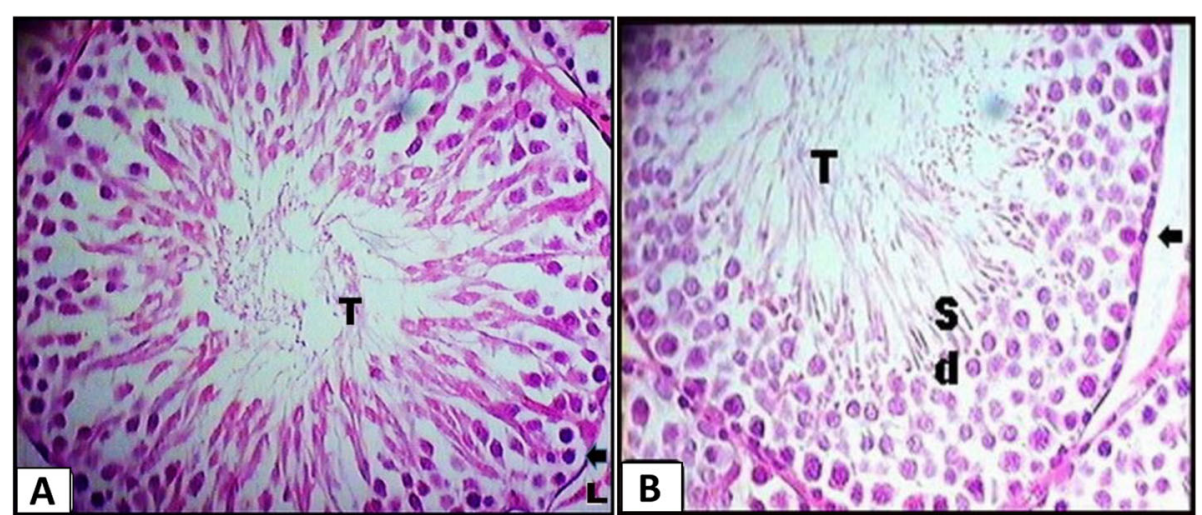

Fig. 1 a A photomicrograph of a C.S. in the testis of control group showing normal seminiferous tubule with rounded, regular outline (arrow), normal spermatogenic cells formed of 4-6 layers at different stages of spermatogenesis. The interstitial spaces show Leydig cells (L) and normal. Notice the appearance of sperm flagella (T). H\&E $(\times 400)$. b A photomicrograph of C.S. of seminiferous tubule from rat fed sesame group II showing the lining germinal epithelium (arrow), regularly rounded seminiferous tubule has several layers of cells in different spermatogenesis stages with spermatids (d), abundant sperm (s), and crowded flagella (T) filling their lumen. H\&E $(\times 400)$

sildenafil citrate depressed both spermatogenesis and spermiogenesis. Al-Fartosi (2009) results are in agreement with those of the present study, since necrosis of somniferous tubules, destruction of cells of the spermatogenic layers, impaired spermatogenesis, arrested spermatogenesis at the level of primary spermatocytes, and disruption of the epithelial lining of the seminiferous tubules were detected. Bairy, Ganesh, and Rao (2009) attributed the histological changes in testis leading to an inadequate sperm production to the reduction of testosterone production. In the treatment group with sesame, significant increase of testosterone level was evident.

On the contrary, Burger, Sikka, Bivalacqua, Lamb, and Hellstrom (2000) showed that sildenafil had no statistically significant effect on sperm count or density in semen samples obtained $1 \mathrm{~h}$ after taking a $100 \mathrm{mg}$ dose of sildenafil or double-blind placebo. Although Zavos and Zarmakoupis-Zavos (2000) recorded a minimal effect of sildenafil on sperm count in men of reproductive age, Alp et al. (2012) reported that sildenafil administration increase sperm count and sperm concentration. On the other hand, consumption of sesame seeds (group V and VI) increases the sperm count and motility of seminiferous tubule as well as improves the testicular morphology when compared with the control group. These beneficial effects of sesame on semen parameters may be attributed to the reactive oxygen species (ROS) and free radical scavenging moiety of sesame lignans (Hemalatha et al. 2004) or sesame inhibits lipid peroxidases which inhibit sperm motility and maturation in the human epididymis (Jeng \& Hou, 2005; Khani,
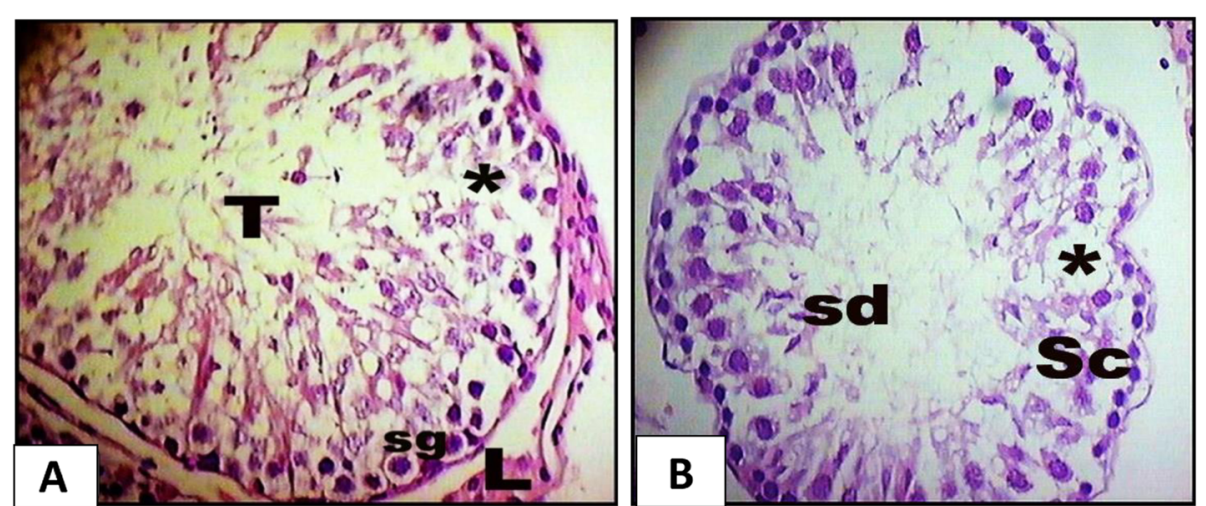

Fig. 2 a A photomicrograph of C.S. of testis from the group (III) showing moderate spermatogenic arrest $\left(^{*}\right)$, few spermatogonia (sg), decreased in number of sperms (T) and spermatids in the seminiferous tubule, and interstitial spaces with Ledge cells (L) H\&E $(\times 400)$. b A photomicrograph of C.S. from the group (IV) rat testis showing disorganized irregular outline seminiferous tubule, disruption of the epithelial lining of the tubules, and impaired arrested spermatogenesis (Sc); detached germ cells, spermatogonia, and deteriorated spermatids (sd); degeneration of spermatogenic elements with appearance of vacuoles $(*)$; and reduction of sperm in the lumen and rarity of Leydig cells. H\&E $(\times 400)$ 


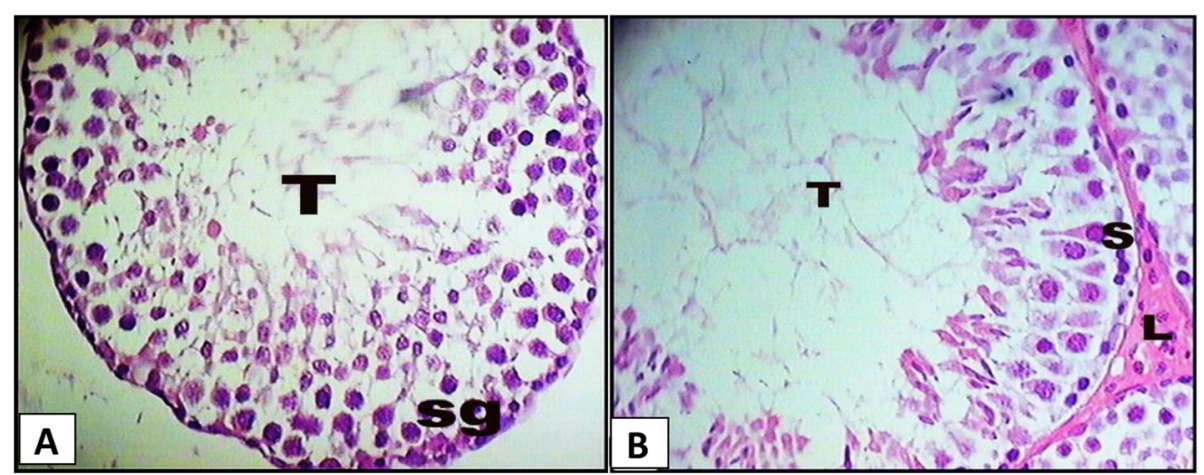

Fig. 3 a A photomicrograph of a cut section in the testis of group $V$ showing certain improvement of histological findings, increased growing of spermatogenic cells, spermatogonia $(\mathrm{sg})$ attaining its architecture, and many spermatozoa in seminiferous tubule $(\mathrm{L})$. H\&E $(\times 400)$. b A photomicrograph of a cut section in the testis of group VI showing discontinuous layer of spermatogonia, many developing spermatozoa with flagella in seminiferous tubule $(T)$, and proliferated Leydig cells $(L)$. H\&E $(\times 400)$

Soroor, \& Fariborz, 2013). Furthermore, it may be attributed to the fact that sesame seeds possess essential nutrients, minerals, and fatty acids which are beneficial during spermiogenesis process. This results were in agreement with those of Shittu et al. (2007). The improvement of sperm count and motility may be due to the antioxidant properties of sesame diets. It has been concluded from this study that sesame has positive effects on spermatogenesis, i.e., sperm production.

The results of the present work revealed that the investigated sperm parameters were significantly decreased in sildenafil-treated groups (groups III and IV). These findings were disagreed with the results of some studies that demonstrated a significant increase in sperm motility and viability (Alp et al., 2012; Shehab, Zaki, Boutros, Emam, \& El-kawas, 2014). Yet, other studies revealed that chronic administration of sildenafil had no adverse effect on semen parameters, while sesame noticeably improved sperm count and motility Khani et al. (2013). Moreover, Shittu et al. (2007) concluded that sesame extract enhances the process of spermatogenesis through a complex of hormonal pathway or increase LH and improves spermatogenesis as stated by Mahabadi, Bafrani, Nikzad, Taherian, and Salehi (2013).

Furthermore, Ezz-Eldin, Gebaly, Abd-Elghany, and Ibrahim (2012) stated that the morphological alterations of the basement membrane are generally accepted to be associated with impaired spermatogenesis. These effects may be according to the changes in the expression of various receptors associated cGMP or responsive effect of these receptors in the brain and this will cause damage of testicular tissues and failure in spermatogenesis as reported by Canteros (1998) and Tocharus, Jeenapongsa, Teakthong, and Smitasiri (2005). The side effects of sildenafil citrate have been reported in the therapeutic dose in different regimes by E-Abdalla, Gebaly, Mostafa, and Amr (2012). Furthermore, sesame seed intake causes an improvement in the testicular parameters, fertility, and sperm production in adult male rats which may be attributed to the antioxidant properties of sesame (Mahabadi et al., 2013). In this meaning, the herbal therapies are better positioned to offer more holistic approaches to improve male reproductive health (Dutta \& Sengupta, 2018).

\section{Conclusion}

In conclusion, we have shown that prolonged and overdose use of sildenafil greatly affects the fertility. However, adding sesame seeds to the diet helps improve the fertility as sesame seeds are a good source of several nutrients minerals, vitamins, and antioxidants.

\section{Abbreviations \\ Sild: Sildenafil; CGMP: Cyclic guanosine monophosphate; ROS: Reactive oxygen species}

\section{Acknowledgments}

The authors would like to thank the faculty members at the Department of Zoology, Faculty of Science, Zagazig University, for their help and support during the preparation and practical part of this work.

\section{Authors' contributions}

AAE and FMG conducted the experiment and analyzed the data. AAE designed the experiment and was a major contributor in writing the manuscript. The authors read and approved the final manuscript.

\section{Funding}

Not applicable

\section{Availability of data and materials}

The datasets used and/or analyzed during the current study are available from the corresponding author on reasonable request.

\section{Ethics approval and consent to participate}

No human subjects are involved in the study. The experimental protocol was approved by the animal care and use committee of the Biochemistry

Department, Faculty of Pharmacy, Zagazig University (Reference number, N/ A).

Consent for publication

Not applicable 


\section{Competing interests}

The authors declare that they have no competing interests.

\section{Author details}

'Zoology Department, Faculty of Science, Sabratha University, Sabratah, Libya. ${ }^{2}$ Zoology Department, Faculty of Science, Zagazig University, Zagazig 44519, Egypt. ${ }^{3}$ Zoology Department, Faculty of Science, Islamic University of Madinah, Medina, Saudi Arabia.

\section{Received: 31 December 2019 Accepted: 15 December 2020} Published online: 07 January 2021

\section{References}

Abbasi, Z., Fatemi, T. S. R., Barati, F., Mazaheri, Y., \& Morovati, H. (2013). The effects of sesame oil on some reproductive parameters of male rats. Iranian Journal of Endocrinology and Metabolism, 15(1), 94-100.

Al-Fartosi, K. (2009). Effects of long-term administration of sildenafil citrate (Viagra) on some sperm characteristics and testis architecture on male rate. Basrah Journal of Veterinary Research, 8(2), 91-103.

Alp, H., Cirit, U., Tas, M., Rifaioglu, M. M., Hatipoglu, N. K., Aytekin, I., ... Eren, L. B. (2012). Effects of sildenafil citrate, isoniazid, and streptomycin on testicular tissue and epididymal semen quality in rats. Urology., 80(4), 9-14.

Bairy, K. L., Ganesh, K., \& Rao, Y. (2009). Effect of acyclovir on the sperm parameters of albino mice. Indian Journal of Physiology and Pharmacology, 53, 327333.

Borchani, C., Besbes, S., Blecker, C. H., \& Attia, H. (2010). Chemical characteristics and oxidative stability of sesame seed, sesame paste, and olive oils. Journal of agriculture, science and. Technology., 12, 585-596.

Burger, M., Sikka, S. C., Bivalacqua, T. J., Lamb, D. J., \& Hellstrom, W. J. (2000). The effect of sildenafil on human sperm motion and function from normal and infertile men. International Journal of Impotence Research, 12, 229-234.

Canteros, G. (1998). Nitric oxide synthase content of hypothalamic explants: Increase by nor epinephrine and activated by NO and CGMP. Proceeding of Natural Academy of Science, USA, 93, 4246-4250.

Cheitlin, M. D., Hutter, A. M., Brindis, R. G., Ganz, P., \& Kaul, S. (1999). Use of sildenafil (Viagra) in patients with cardiovascular disease. Circulation, 99, 168-177.

Conti, C. R., Pepine, C. J., \& Sweeney, M. (1999). Efficacy and safety of sildenafil citrate in the treatment of erectile dysfunction in patients with ischemic heart disease. The American Journal of Cardiology, 83, 29-34.

Corbin, J., Rannels, S., Neal, D., Chang, P., Grimes, K., Beasley, A., \& Francis, S. (2003). Sildenafil citrate does not affect cardiac contractility in human or dog heart. Current Medical Research and Opinion, 19, 747-752.

Drury, R. A., \& Wallington, E. A. (1980). Carleton's histological technique $5^{\text {th }}$ edition. London, New York, Toronto: Oxford Univ. Press.

Dutta, S., \& Sengupta, P. (2018). Medicinal herbs in the management of male infertility. Journal of pregnancy and production. V., 2(1), 1-6.

E-Abdalla, E., Gebaly, Z. M., Mostafa, A. A., \& Amr, I. M. (2012). Evaluation the effect of sildenafil citrate (sc or Viagra) on senile albino rat testis (histological and biochemical study). The Egyptian Journal Hospital Medicine, 49, 911-932.

Eardley, I. (2001). Efficacy and safety of sildenafil citrate in the treatment of men with mild to moderate erectile dysfunction. The British Journal of Psychiatry, $178,325-330$

Eherer, A. J. I., Schwetz, H. F., Hammer, T., Petnehazy, S. J., Scheidl, K., Weber, \& Krejs, G. J. (2002). Effect of sildenafil on esophageal motor function in healthy subjects and patients with esophageal motor disorders. Gut, 50, 758-764.

El Khier, M. K. S., Ishag, K. E. A., \& Yagoub, A. E. A. (2008). Chemical composition and oil characteristics of sesame seed cultivars grown in Sudan. Research Journal of Agriculture and Biological Sciences, 4(6), 761-766.

Elleuch, M., Besbes, S., Roiseux, O., Blecker, C., \& Attia, H. (2007). Quality characteristics of sesame seeds and by-products. Food Chemistry, 103, 641650.

Eweka, A. O., \& Eweka, A. (2011). The effects of sildenafil citrate on the liver and kidneys of adult Wistar rats (Rattus norvegicus). A histological study. Tech. Pub. , Rijeka, Croatia, 5, 117-128.

Ezz-Eldin, E. A., Gebaly, Z. M., Abd-Elghany, A. M., \& Ibrahim, M. A. (2012). Evaluation the effect of sildenafil citrate (SC or Viagra) on senile albino rat testis (histological and biochemical study). Egyptian Journal of Hospital Medicine, 49, 911-932.

Fazan Jr., R., Huber, D. A., Silva, C. A., da Silva, V. J., Salgado, M. C., \& Salgado, H. C. (2008). Sildenafil acts on the central nervous system increasing sympathetic activity. Journal of Applied Physiology, 104, 1683-1689.
Goldberg, D. J., French, B., McBride, M. G., Marino, B. S., \& Mirarchi, N. (2011). Impact of oral sildenafil on exercise performance in children and young adults after the fontan operation: A randomized, double-blind, placebocontrolled, crossover trial. Circulation, 123, 1185-1193.

Gumus, B., Vatansever, H. S., Müezzinoglu, T., Müftüoglu, S., \& Kaymaz, F. (2004). Histopathological effects of sildenafil citrate on rat corpus cavernosum. Acta Histochemica, 106, 37-45.

Hemalatha, S. R., Raghunath, M., \& Ghafoorunissa (2004). Dietary sesame oils inhibits iron-induced oxidative stress in rats. The British Journal of Nutrition, 92, 581-587.

Jarrar, B. M. (2011). Histological alterations in the testicular tissue induced by sildenafil overdoses. Bentham Science Publishers Ltd., 5(2), 99-103.

Jeng, K. C., \& Hou, R. C. (2005). Sesamin and sesamolin: Natures therapeutic lignans. Current Enzyme Inhibition, 1, 11-20.

Ji, H., Shen, H., Uhanova, J., Zhang, M., Minuk, G. Y., \& Gong, Y. (2005). Effects of sildenafil citrate on hepatic function and regeneration in normal and alcohol fed rats. Liver International, 25, 913-919.

Kalsi, J. S., \& Kell, P. D. (2004). Update on oral treatments for male erectile dysfunction. Journal of the European Academy of Dermatology and Venereology, 18, 267-274.

Khani, M., Soroor, R. B., \& Fariborz, M. (2013). Effect of sesame on sperm quality of infertile men. Journal of Research in Medical Sciences: The Official Journal of Isfahan University of Medical Sciences, 18(3), 184-187.

Kyratsas, C., Dalla, C., Anderzhanova, E., Polissidis, A., Kokras, N., Konstantinides, K., \& Daifoti, Z. P. (2013). Experimental evidence for sildenafil's action in the central nervous system: Dopamine and serotonin changes in the medial preoptic area and nucleus accumbens during sexual arousal. The Journal of Sexual Medicine, 10, 719-729.

Lauver, D. A., Carey, E. G., Bergin, I. L., Lucchesi, B. R., \& Gurm, H. S. (2014). Sildenafil citrate for prophylaxis of nephropathy in an animal model of contrast-induced acute kidney injury. PLoS One, 9, 10-13.

Mahabadi, A. J., Bafrani, H. H., Nikzad, H., Taherian, A., \& Salehi, M. (2013). Effect of diet contains sesame seed on adult wistar rat testis. International Journal of Morphology, 31(1), 197-202.

Nayar, N. M., \& Mehra, K. L. (2002). Sesame: Its uses, botany, cytogenetics, and origin. Economic Botany, 24, 20-31.

Reshma, M. V., Balachandran, C., Arumughan, C., Sunderasan, A., \& Sukumaran, D. (2010). Extraction, separation and characterisation of sesame oil lignan for nutraceutical applications. Food Chemistry, 120, 1041-1046.

Saalu, L. C., Togun, V. A., Oyewopo, A. O., \& Raji, Y. (2006). Artificial cryptorchidism and the moderating effect of melatonin (nacetyl. 5 methoxy tryptamin) in Sprague-Dawley rats. Journal of Applied Sciences, 6(14), 2889-2894.

Salam, A., Rokonujjaman, A., Rahman, U., Sultana, N., \& Sultan, Z. (2015). Study of in vitro interaction of sildenafil citrate with bovine serum albumin by fluorescence spectroscopy. Journal of Pharmacy and Pharmacology, 6, 94-101.

Salloum, F., Yin, C., Xi, L., \& Kukreja, R. C. (2003). Sildenafil induces delayed preconditioning through inducible nitric oxide synthase-dependent pathway in mouse heart. Circulation Research, 92, 595-597.

Scipioni, A., Stefanini, S., Santone, R., \& Giorgi, M. (2005). Immuno-histochemical localization of PDE5 in Leydig and myoid cells of prepuberal and adult rat testis. Histochemistry and Cell Biology, 124, 401-407.

Shehab, M. I., Zaki, N. N., Boutros, M. E., Emam, H. T., \& El-kawas, A. B. (2014). The possible protective effect of sildenafil on colchicine induced infertility in rats. International Journal of Advanced Research, 2(5), 939-951.

Shittu, L. A., Shittu, R. K., Adesite, S. O., Ajala, M. O., Bankole, M. A., Benebo, A. S., ... Ashiru, O. A. (2007). Sesame radiatum phytoestrogens stimulate spermatogenic activity and improve sperm quality in adult male Sprague Dawley rat testis. International Journal of Morphology, 26(3), 643-652.

Tocharus, C., Jeenapongsa, R., Teakthong, T., \& Smitasiri, Y. (2005). Effects of longterm treatment of Butea superba on sperm motility and concentration. Naresuan University Journal, 13, 11-17.

Tunde-Akintunde, T. Y., Oke, M. O., \& Akintunde, B. O. (2012). Sesame seed, oilseeds, (pp. 81-98).

Tuorkey, M., \& Abdul Aziz, K. (2012). Effects of sex enhancing drugs on different organs in male Swiss albino mice: Values of safety. Scientific Reports, 1, 133-145.

Uthayathas, S., Karuppagounder, S., Thrash, B. M., Parameshwaran, K., Supperania, M. V., \& Dhanasekaran, M. (2007). Versatile effects of sildenafil, recent pharmacological applications. Pharmacological Reports, 59(2), 150-163.

Yang, Y., Li, Z., Wu, X., Chen, H., Xu, W., Xiang, Q., .. Huang, Y. (2017). Direct reprogramming of mouse fibroblasts toward Leydig-like cells by defined factors. Stem Cell Reports, 8(1), 39-53. 
Zavareh, M., Hoogenboom, G., Rahimian, M. H., \& Arabd, A. (2008). A decimal code to describe the growth stages of sesame (Sesamum orientale L.). International Journal of Plant Production, 2(3), 193-206.

Zavos, P. M., \& Zarmakoupis-Zavos, P. N. (2000). The use of sildenafil citrate for treatment of male infertility in males with erectile dysfunction. Journal of Obstetrics and Gynecology, 95(4), S49-S50.

\section{Publisher's Note}

Springer Nature remains neutral with regard to jurisdictional claims in published maps and institutional affiliations.

Submit your manuscript to a SpringerOpen ${ }^{\circ}$ journal and benefit from:

- Convenient online submission

- Rigorous peer review

- Open access: articles freely available online

- High visibility within the field

- Retaining the copyright to your article

Submit your next manuscript at $\boldsymbol{\sim}$ springeropen.com 